\section{In Vitro Periodontal Ligament Cell Viability in Different Storage Media}

\author{
Meenakshi Sharma
}

The aim of this study was to evaluate the viability of periodontal ligament cells of avulsed teeth in three different storage media. Forty-five mature premolars extracted for orthodontic therapeutic purposes were randomly and equally divided into three groups according to the storage medium: milk (control), rice water and egg white. After placing extracted teeth for $30 \mathrm{~min}$ in storage media, the scrapings of the periodontal ligament (PDL) were collected in Falcon tubes containing collagenase in $2.5 \mathrm{~mL}$ of phosphate buffer saline and were incubated for $30 \mathrm{~min}$ and centrifuged for $5 \mathrm{~min}$ at $800 \mathrm{rpm}$. Cell viability was analyzed by Trypan blue exclusion. Rice water had a significantly higher number of viable cells compared to egg white and milk. There was no statistically significant difference between egg white and milk. Rice water may be able to maintain PDL cell viability of avulsed teeth better than egg white or milk.
Department of Pedodontics and Preventive Dentistry Govt. Dental College Jaipur, Rajasthan, India

Correspondence: Dr. Meenakshi Sharma, Assistant Professor, Department of Pedodontics and Preventive Dentistry, Govt. Dental College, Jaipur, Rajasthan, India. Tel:+91-86-9686-0009. e-mail: dr.mesharma@gmail.com

\section{Introduction}

Avulsion or exarticulation is the complete displacement of a tooth from its alveolar socket due to traumatic injury (1). It is one of the most complex forms of dental injury, which may occur as a result of fight and sports in the permanent dentition, while falls against hard objects is a frequent cause in the primary dentition (2). Exarticulation leads to injury to periodontal ligament tissues along with severance of the neurovascular bundle of the dental pulp at the apical foramen resulting in pulp necrosis. In such condition, the tooth should be maintained in a suitable medium until it is replanted by a dentist as soon as possible (3). Research has shown that an exarticulated tooth can be replanted without complications if it is re-inserted into the socket within $20 \mathrm{~min}$ when stored dry and within 1 to 3 $\mathrm{h}$ if placed in a suitable storage medium. When the tooth is maintained dry for more than 20 min, its periodontal ligament cells begin to necrose and once replantated, inflammation and resorption develop in proportion to the extra-oral dry time (4). Saliva, milk, Hank's balanced salt solution (HBSS), $\alpha$ Minimum essential medium (MEM), propolis, Viaspan, soy milk and many more storage media have been proposed for storing avulsed teeth (5-7). Among them, HBSS is recommended by the American Associations of Endodontists (AAE) as a storage medium of choice for treatment of avulsed teeth because of its ability to provide long-term preservation of PDL cell viability. However, HBSS is not commonly available in most places such as school, home, camps and sports field settings where traumatic events usually occur as children are physically active at these places (2). Hence, there is need to identify a medium that is readily available and yet equally effective as well.

This study investigated the capacity of rice water and egg white to maintain the viability of periodontal ligament cells compared with milk.

\section{Material and Methods}

Forty-five non-carious human mature premolars with apparently normal periodontium and closed apices, extracted for orthodontic therapeutic purposes, were included in this study. The random and equal distribution of the 45 extracted teeth was done in 3 groups, according to the storage medium: milk (control group), rice water and egg white. Regular pasteurized milk (Saras Dairy, Bhilwara, India) was used at room temperature. Rice water was prepared by boiling six cups of water in a vessel over medium heat. Once the water boiled, one cup of rice was added and stirred frequently. After the rice was cooked, the liquid was separated from the rice using a sieve and then cooled. For obtaining egg white, egg was cracked on the edge of a bowl and then was turned upright. The shell was opened into two halves while keeping the yolk in lower half. Over the bowl, the content was poured from one half of the broken shell into the other, allowing the egg white to fall into the bowl, but the yolk was kept intact in the egg shell halves. The process was repeated until all the white had fallen into the bowl and only yolk was left in the shell.

Following extractions, the teeth were held with forceps by the crown and the coronal $3 \mathrm{~mm}$ of periodontal ligament (PDL) were scraped with a curette to remove the cells damaged during extraction (8). Immediately after this procedure, teeth were left in mud for 15 min to simulate avulsion injury (9) and then placed in the three storage media for $30 \mathrm{~min}$. Following storage in each medium, the teeth were held with tweezers by grasping the crown portion and the root surface was cleaned by irrigating twice with 
sterile isotonic saline to remove the storage media residues.

The cleaned teeth were then placed in a Petri dish and the apical two thirds of the root surfaces (as measured from the epithelial attachment) were scraped with scalpel blade \# 15 to obtain the PDL cells. The obtained scrapings were added to a Falcon tube containing $2.5 \mathrm{~mL}$ of phosphate buffer. To the above mixture, $0.5 \mathrm{mg}$ of collagenase enzyme was added $(0.2 \mathrm{mg}$ for every $\mathrm{mL}$ of phosphate buffer was weighed on a digital scale) and then this mixture was incubated for $30 \mathrm{~min}$.

Following incubation, the Falcon tubes containing the above mixture were centrifuged for $5 \mathrm{~min}$ at $800 \mathrm{rpm}$ (8). The obtained supernatant liquid was discarded and the centrifuged residue was collected. To this, an equal volume of $0.4 \%$ Trypan blue stain was added and well mixed. Trypan blue stain is a vital stain, it stains the nonvital cells blue and the vital cells appear colorless or pink (10). Following staining, the cells were observed by a hemocytometer under optical microscope (11).

\section{Determination of the Number of Cells (Total and Viable)}

The cells were viewed under microscope at 100x magnification. The number of cells (total and non-viable) was counted overlying $4 \times 1 \mathrm{~mm}^{2}$ areas of the counting chamber. The percent number of viable cells was obtained as follows (10):

$$
\frac{\text { (total cells }- \text { stained cells) }}{\text { total cells }} \times 100
$$

Means and standard deviation of number of viable cells of different storage media were calculated and subjected to t-test and one-way analysis of variance for comparison among the storage media. Significance level was set at 5\%.

\section{Results}

Table 1 shows that the teeth stored in rice water presented a significantly higher percentage of viable PDL cells (85.38\%) compared with egg white (75.8\%) and milk (74.07\%) (Fig. 1). Egg white showed higher number of

Table 1. Mean values and standard deviations of viable, non-viable and \%viable PDL cells count in control and experimental groups

\begin{tabular}{lcccc}
\hline $\begin{array}{l}\text { Storage } \\
\text { medium }\end{array}$ & Total & Viable cells & $\begin{array}{c}\text { Non- } \\
\text { viable } \\
\text { cells }\end{array}$ & $\begin{array}{c}\% \text { Viable } \\
\text { cells }\end{array}$ \\
\hline Milk & $135.2 \pm 7.8$ & $100.1 \pm 7.3$ & $35.1 \pm 6.7$ & $74.07 \%$ \\
$\begin{array}{l}\text { Rice } \\
\text { water }\end{array}$ & $130.3 \pm 7.4$ & $111.1 \pm 8.6$ & $19.2 \pm 5.8$ & $85.38 \%$ \\
Egg white & $134.5 \pm 11.8$ & $101.9 \pm 6.3$ & $31.5 \pm 6.3$ & $75.8 \%$ \\
\hline
\end{tabular}

viable cells compared with milk, but without statistically significant difference.

\section{Discussion}

Favorable healing after an avulsion injury requires quick emergency intervention followed by evaluation and possible treatment at decisive times during the healing phase. Santos et al. (10) have shown that replanting the avulsed tooth within 5 min results in much higher reattachment and thereby the tooth has the best prognosis. In cases where replantation cannot be done immediately, storing the tooth in suitable storage medium maintains viability of PDL cells on the root surface and decreases incidence of root resorption. The fundamental philosophy for the storage of avulsed teeth is that they should be stored in a medium that most closely replicates the oral environment.

Many of the storage media such as Hank's Balanced Salt Solution, Viaspan and Eagle's medium may be considered ideal because of their cell reconstitution ability $(5,6)$. However, the major disadvantages of these media are their high cost and unavailability (8). It is fundamental that the storage medium be easily available to allow replantation of avulsed teeth within time for better prognosis. Hence the present study was conducted to evaluate and compare the effectiveness of rice water and egg white as alternate storage media for avulsed teeth.

Fibroblast function is known to be affected by age, trauma and inflammation. Therefore, non-carious mature human premolars were selected from young healthy individuals without periodontal disease extracted for orthodontic therapeutic purposes (12).

Avulsion injury was simulated by extraction of tooth and leaving it on mud for at least $15 \mathrm{~min}$. This is the time the victim and the attendant take to recover from the traumatic event and act appropriately(8). Pohl et al. stated

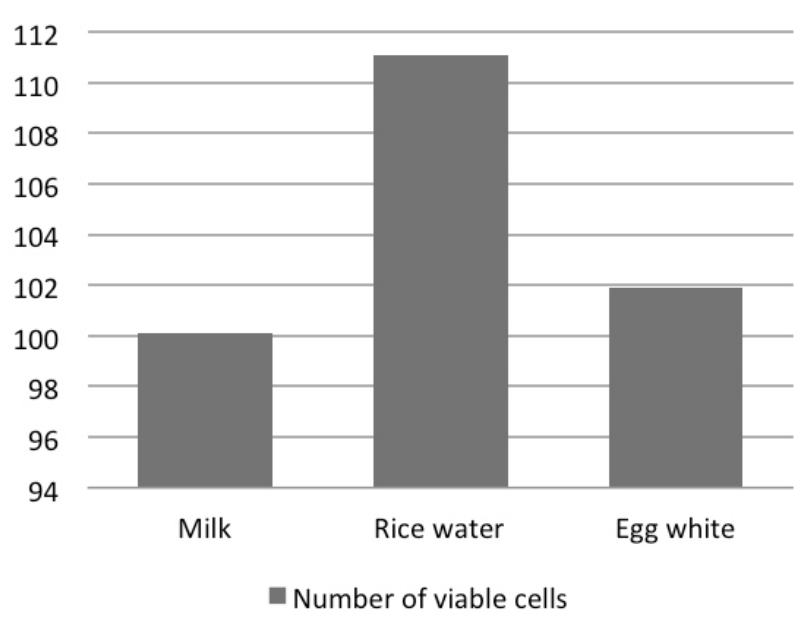

Figure 1. Number of viable cells in milk, rice water and egg white. 
that 15 min dry time is the time when PDL cells remain in non-compromised state (13). Other investigators have shown that at $2 \mathrm{~h}$ dry time, no vital PDL cells remain (14). A 15 min dry time was chosen in the current investigation, as this seems to be a critical time at which damage has been done to many PDL cells, yet some cells remain for assessment. Following the 15 min dry time, the teeth were placed in different storage media for $30 \mathrm{~min}$. This period is very important because the periodontal cells are damaged during this time. Hence preservation of teeth in the storage media may reduce the damage (15). A former study stated that if the avulsed tooth is treated with vitamin $\mathrm{C}$ before replantation it shows more ankylosis and replacement resorption than inflammatory resorption (16).

Milk was chosen as the positive control in the present study because of its several advantages. It has the physiologic osmolality similar to that of serum and contains fewer bacteria as compared to saliva. It is one of the most frequently used storage media (17).

Rice water was chosen as a storage medium because of its ease of availability in India where around 70\% of the population eats rice. Its low sodium content and useful quantities of potassium, Vitamin $B$, thiamine and niacin makes it an extremely healthy food. According to Medicinal Book of Malayan Medicine, boiled rice "greens" can be used when there is acute inflammation of the inner body tissues (18).

The egg white was chosen due to its nutritive constituents. Egg white from a single egg contains $4.7 \mathrm{~g}$ of 40 different proteins, $0.3 \mathrm{~g}$ of carbohydrate, $62 \mathrm{mg}$ of sodium and the remaining being water (19).

Ragnarsson's (20) and Doyle's (21) methods are extensively quoted in literature to evaluate the efficacy of the different storage media in preserving the viability of dental fibroblasts. In Ragnarsson's method (20), the fibroblasts are first removed from the root surfaces and added to the storage media for culturing. The viability of cells was evaluated at different time intervals and counted. In Doyle's method (21) the extracted tooth is directly placed in storage medium. After a pre-determined time, the tooth is removed from the medium and PDL cells are isolated to evaluate cell viability. In the present study, Doyle's method was followed because it more closely replicates the actual clinical scenario.

The root surfaces were treated with collagenase type 1 as was performed by Pillegi et al. (15) to quantify the number of viable PDL cells and to preserve maximum cell viability. This procedure allowed rapid cell retrieval and maintained maximum cellular integrity $(22,23)$.

Trypan blue exclusion staining technique was used as it is quick, easily performed and distinctively differentiates nonviable cells from viable cells. The reactivity of Trypan blue is based on the fact that the chromophore on the cell membrane is negatively charged and does not take up the stain unless the membrane is damaged. Therefore, all the cells that exclude the dye are viable (10). Trypan blue stain used in the study assessed only the viability of cells but not their actual physiological health and metabolic capabilities (8).

The result shows that the maximum percentage of viable cells was found in rice water (85.38\%) followed by egg white (75.8\%) and least in milk (74.07\%).

Rice water maintained the highest number of viable cells. This could be explained by the fact that it has low sodium content, useful quantities of potassium, Vitamin $\mathrm{B}$, thiamine and niacin. It also has anti-inflammatory properties. The iron and zinc in its composition help in the synthesis of collagen (8).

Egg white maintained less number of viable cells than rice water. This may be attributed to the high $\mathrm{pH}$ (9.38) and also to the large amount of proteins in egg white that may act as a foreign body.

In the present study, milk storage preserved the smallest number of viable cells $(74.04 \%)$. This small number of viable cells could be due to various enzymes present in the milk, which could be potentially harmful to the fibroblasts of the periodontal ligament. According to Gamsen et al. (8), milk does not have ability to reconstitute depleted cell metabolites and restore viability of periodontal ligament cells, and cells stored in the milk lack the cell energy and ions to permit the repopulation of the periodontal ligament. Blomlof et al. (24) found that milk was a compatible storage medium only when it was cold and fresh.

It may be concluded that immediate replantation is the best treatment for an exarticulated tooth, provided the tooth has viable PDL cells at the time of replantation. If immediate replantation is not possible, a storage medium should best preserve the viability of PDL cells until the tooth is replanted. Under the conditions of this study, rice water may be able to maintain PDL cell viability better if compared to egg white or milk. Further research, included in the form of in vivo studies is needed to investigate for more precise results and comparison, and whether rice water if maintained at lower temperature or at extended extra oral dry time can maintain viability of PDL cells.

\section{Resumo}

O objetivo deste estudo foi avaliar a viabilidade das células do ligamento periodontal de dentes avulsionados armazenados em três diferentes meios. Quarenta e cinco pré-molares com formação radicular completa extraidos por razões terapêuticas foram aleatoriamente distribuidos em três grupos, de acordo com o meio de armazenagem: leite (controle), água de arroz e clara de ovo). Após armazenar os dentes avulsionados por 30 min no meio, raspas do ligamento periodontal (LPD) foram coletadas em tubos Falcon contendo 2,5 mL de solução tamponada de soro fosfatado, incubadas por $30 \mathrm{~min}$ e a seguir centrifugadas por $5 \mathrm{~min}$ a $800 \mathrm{rpm}$. A 
viabilidade celular foi analisada pelo método de exclusão do Azul de Trypan. A água de arroz teve um número significativamente maior de células viáveis em comparação com o leite e a clara de ovo. Não houve diferença estatisticamente significativa entre o leite e a clara de ovo. A água de arroz pode ser capaz de manter a viabilidade das células do PDL de dentes avulsionados, melhor que o leite ou a clara de ovo.

\section{References}

1. Application of the international classification of disease and stomatology. Geneva; World Health Organization, 1992.

2 Andreasen J0. Etiology and pathogenesis of traumatic dental injuries. A clinical study of 1,298 cases. Scand J Dent Res 1970;78:329-342.

3. Hamilton FA, Hill FJ, Mackie IC. Investigation of lay knowledge of the management of avulsed permanent incisors. Endod Dent Traumatol 1997;13:19-23.

4. Andreasen JO, Borum MK, Jacobsen HL, Andreasen FM. Replantation of 400 avulsed permanent incisors. 1. Diagnosis of healing complications. Endod Dent Traumatol 1995;11:51-58.

5. Chamorro MM, Regan JD, Opperman LA, Kramer PR. Effect of storage media on human periodontal ligament cell apoptosis. Dent Traumatol 2008;24:11-16.

6. Moura CCG, Soares PBF, Reis MVP, Fernandes Neto AJ, Soares CJ. Soy milk as a storage medium to preserve human fibroblast viability: an in vitro study. Braz Dent J 2012;23:559-563.

7. Borum MK, Andreasen JO. Sequelae of trauma to primary maxillary incisors. 1. Complications in primary dentition. Endod Dent Traumatol 1998;14:31-44.

8. Martin MP, Pileggi R. A quantitative analysis of propolis: a promising new storage media following avulsion. Dent Traumatol 2004;20:85-89.

9. Geetha H, Girija S, Kumaraswamy. A promise by coconut water. Karnataka State Dental Journal 2008;27:9-11.

10. Santos CLV, Sonoda CK, Poi WR, Panzarini SR, Sundefeld MLMM, Negri MR. Delayed replantation of rat teeth after use of reconstituted powdered milk as a storage medium. Dent Traumatol 2009;25:51-57.

11. Sanghavi T, Shah N, Parekh V, Singbal K. Evaluation and comparison of efficacy of three different storage media, coconut water, propolis, and oral rehydration solution, in maintaining the viability of periodontal ligament cells. J Conserv Dent 2013;16:71-74.
12. Khademi AA, Saei S, Mohajeri MR, Mirkeshti N, Ghassami F, Torabi N, et al.. A new storage medium for an avulsed tooth. J Contemp Dent Pract 2008;9:1-5.

13. Pohl $Y$, Filippi $A$, Kirschner $H$. Results after replantation of avulsed permanent teeth. II. Periodontal healing and the role of physiologic storage and antiresorptive-regenerative therapy. Dent Traumatol 2005;21:93-101.

14. Andreasen J0. Effect of extra oral period and storage media upon periodontal and pulpal healing after replantation of mature permanent incisors in monkeys. Int J Oral Surg 1981;10:43-53.

15. Pileggi R, Dumsha TC, Nor JE. Assessment of post-traumatic PDL cells viability by novel collagenase assay. Dent Traumatol 2002;18:186-189.

16. Panzarini SRP, Carvalho ACP, Poi WR, Sonoda CK. Use of vitamin C in delayed tooth replantation. Braz Dent J.2005;16:17-22.

17. Lindskog $S$, Andersson L, Hedström KG, Hammarström L. Storage of experimentally avulsed teeth in milk prior to replantation. Dent Res 1983;62:912-916.

18. Ahuja U, Ahuja SC, Thakrar R, Singh RK. Rice - A nutraceutical Asian agri- history. 2008;12:93-108.

19. DS Robinson, JB Monsey. Studies on the composition of egg-white ovomucin. Biochem J 1971;121:537-547.

20. Ragnarsson B, Carr G, Daniel JC. Basic biological sciences isolation and growth of human periodontal ligament cells in vitro. J Den Res 1985;64:1026-1030.

21. Doyle DL, Dumsha TC, Sydiskis RJ. Effect of the soaking in Hank's balanced salt solution or milk on PDL cell viability of dry stored human teeth. Endod Dent Traumatol 1998;14:221-224.

22. Abdul S, James W, Aggarwal S, Bretz W, Baugh D. Effect of propolis on human fibroblasts from pulp and periodontal ligament. J Endod 2004;30:359-361.

23. Gamson EK, Dumshan TC, Sydiskis R. The effect of drying time of periodontal ligament cell viability. J Endod 1992;18:189.

24. Blomlof $L$, Otteskog $P_{1}$ Hammarstrom L. Effect of storage in media with different ion strength and osmolarities on human periodontal ligament cells. Scand J Dent Res 1981;89:180-187.

Received January 13, 2016 Accepted May 21, 2016 